\title{
Medical-grade honey enriched with antimicrobial peptides has enhanced activity against antibiotic-resistant pathogens
}

\author{
P. H. S. Kwakman • L. de Boer • C. P. Ruyter-Spira - T. Creemers-Molenaar • \\ J. P. F. G. Helsper • C. M. J. E. Vandenbroucke-Grauls • S. A. J. Zaat • A. A. te Velde
}

Received: 10 May 2010 /Accepted: 22 September 2010 / Published online: 7 October 2010

(C) The Author(s) 2010. This article is published with open access at Springerlink.com

\begin{abstract}
Honey has potent activity against both antibioticsensitive and -resistant bacteria, and is an interesting agent for topical antimicrobial application to wounds. As honey is diluted by wound exudate, rapid bactericidal activity up to high dilution is a prerequisite for its successful application. We investigated the kinetics of the killing of antibioticresistant bacteria by RS honey, the source for the production of Revamil $^{\circledR}$ medical-grade honey, and we aimed to enhance the rapid bactericidal activity of RS honey by enrichment with its endogenous compounds or the addition of antimicrobial peptides (AMPs). RS honey killed antibiotic-resistant isolates of Pseudomonas aeruginosa, Staphylococcus epidermidis, Enterococcus faecium, and
\end{abstract}

P. H. S. Kwakman • L. de Boer $\cdot$

C. M. J. E. Vandenbroucke-Grauls · S. A. J. Zaat $(\square)$

Department of Medical Microbiology, Academic Medical Center, University of Amsterdam,

Meibergdreef 15,

1105 AZ Amsterdam, The Netherlands

e-mail: s.a.zaat@amc.uva.nl

C. P. Ruyter-Spira • J. P. F. G. Helsper

Plant Research International,

Wageningen, The Netherlands

T. Creemers-Molenaar

Bfactory Health Products,

Rhenen, The Netherlands

C. M. J. E. Vandenbroucke-Grauls

Department of Medical Microbiology and Infectious Diseases,

VU Medical Center,

Amsterdam, The Netherlands

A. A. te Velde

Tytgat Institute for Liver and Intestinal Research, Academic

Medical Center, University of Amsterdam,

Amsterdam, The Netherlands
Burkholderia cepacia within $2 \mathrm{~h}$, but lacked such rapid activity against methicillin-resistant S. aureus (MRSA) and extended-spectrum beta-lactamase (ESBL)-producing Escherichia coli. It was not feasible to enhance the rapid activity of RS honey by enrichment with endogenous compounds, but RS honey enriched with $75 \mu \mathrm{M}$ of the synthetic peptide Bactericidal Peptide 2 (BP2) showed rapid bactericidal activity against all species tested, including MRSA and ESBL E. coli, at up to 10-20-fold dilution. RS honey enriched with BP2 rapidly killed all bacteria tested and had a broader spectrum of bactericidal activity than either BP2 or honey alone.

\section{Introduction}

Antibiotic-resistant bacteria pose a very serious threat to public health. For all antibiotic classes, including the major last-resort drugs, resistance is increasing worldwide [1, 2]. Even more alarming, very few new antibiotics are being developed $[1,3]$, so alternative antimicrobial strategies are urgently needed.

The potent in vitro activity of honey against antibioticresistant bacteria [4] and its successful application in the treatment of chronic wound infections not responding to antibiotic therapy [5] resulted in a revival of the interest in honey as an antibacterial agent [6-8]. Important prerequisites for the application of honey as an antimicrobial agent are reproducible and rapid bactericidal activity [9] and knowledge of its mechanism of action.

Honeys collected from the natural environment, including Manuka honey, which is used for the production of most currently available medical-grade honeys, show large variation in antibacterial activity $[10,11]$. Manuka honey can contain very high levels of methylglyoxal (MGO), which is regarded 
to be the major antibacterial compound in this honey $[12,13]$. The honey used as a source for Revamil ${ }^{\circledR}$ medical-grade honey (RS honey) is produced under standardized conditions in greenhouses, and is sterilized by gamma irradiation to kill potentially present bacterial spores. Gamma irradiation is known not to affect honey bactericidal activity [14]. Revamil ${ }^{\circledR}$ has broad-spectrum, batch-to-batch reproducible bactericidal activity in vitro. It has been shown that it can strongly diminish microbial colonization of the human skin [15]. We have recently identified all major bactericidal factors in RS honey, i.e., its high sugar concentration, $\mathrm{H}_{2} \mathrm{O}_{2}$, low $\mathrm{pH}$, MGO, and the cationic antimicrobial peptide (AMP) bee defensin-1 [16].

AMPs are known for their potent, rapid, broad-spectrum microbicidal activity. Their supposed mechanism of action is the direct targeting of microbial membranes [17], although AMPs may also have intracellular targets [18, 19]. A cationic domain of these peptides specifically interacts with the negatively charged outer surfaces of microorganisms and a hydrophobic domain is required for membrane perturbation or penetration, causing either membrane disruption or translocation into the cell [20, 21]. Some bacteria have evolved mechanisms to reduce their outer surface negative charge to reduce susceptibility to AMPs [22]. Since this involves complex biosynthetic pathways, the risk for rapid resistance development against AMPs is considered to be low [22].

In the current study, we show that RS honey has potent bactericidal activity, but this requires prolonged exposure of the target organisms. RS honey lacks rapid bactericidal activity against several important antibiotic-resistant wound pathogens, including methicillin-resistant Staphylococcus aureus. We were not able to augment the bactericidal activity of RS honey by enrichment with endogenous honey bactericidal compounds, but addition of the synthetic AMP Bactericidal Peptide 2 (BP2) did result in broad-spectrum rapid bactericidal activity.

\section{Materials and methods}

\section{Honey}

Unprocessed Revamil source (RS) honey was kindly provided by Bfactory Health Products (Rhenen, The Netherlands).

Peptides

BP2 (GKWKLFKKAFKKFLKILAC) and LL-37 were synthesized at Pepscan Systems (Lelystad, The Netherlands) using solid-phase Fmoc (9-fluorenylmethoxycarbonyl) chemistry with a free amine at the $\mathrm{N}$-terminus and a free amide at the C-terminus. Peptides were highperformance liquid chromatography (HPLC)-purified and the purity $(>95 \%)$ and mass were confirmed by ion-spray mass spectrometry. The lack of disulfide formation between free cysteines of BP2 was confirmed by quadrupole time-of-flight/mass spectrometry (Q-TOF/ MS) analysis.

\section{Microorganisms}

Bactericidal activity was assessed against clinical isolates of methicillin-resistant $S$. aureus (MRSA), methicillin-resistant S. epidermidis (MRSE), vancomycin-resistant Enterococcus faecium (VREF), extended-spectrum beta-lactamase (ESBL)producing Escherichia coli (E. coli ESBL) and Pseudomonas aeruginosa ESBL, and against the Burkholderia cepacia ATCC 25416 type strain. The oxacillin susceptibility of $S$. aureus and $S$. epidermidis and the vancomycin susceptibility of E. faecium were determined by Etest (AB Biodisk) according to the manufacturer's instructions. ESBLs were identified as described by Al Naiemi et al. [23].

Determination of $\mathrm{H}_{2} \mathrm{O}_{2}$ concentration in honey

Hydrogen peroxide concentrations in honey were determined quantitatively using a modification of a method described by White and Subers [24]. Undiluted and ten-fold-diluted samples of honey $(40 \mu l)$ were mixed in wells of microtiter plates with $135 \mu \mathrm{l}$ reagent, consisting of $50 \mu \mathrm{g} / \mathrm{ml} \mathrm{o-dianisidine} \mathrm{(Sigma)} \mathrm{and} 20 \mu \mathrm{g} / \mathrm{ml}$ horseradish peroxidase type IV (Sigma) in $10 \mathrm{mM}$ phosphate buffer $\mathrm{pH}$ 6.5. o-Dianisidine was freshly prepared as a $1 \mathrm{mg} / \mathrm{ml}$ stock in demineralized water and peroxidase was diluted from a $10 \mathrm{mg} / \mathrm{ml}$ stock in $10 \mathrm{mM}$ phosphate buffer $\mathrm{pH} 6.5$ stored at $-20^{\circ} \mathrm{C}$. After $5 \mathrm{~min}$ of incubation at room temperature, reactions were stopped by the addition of $120 \mu \mathrm{l} 6 \mathrm{M} \mathrm{H}_{2} \mathrm{SO}_{4}$ and absorption at $540 \mathrm{~nm}$ was measured. Hydrogen peroxide concentrations were calculated using a calibration curve of two-fold serial dilutions of $\mathrm{H}_{2} \mathrm{O}_{2}$ ranging from 2,200 to $2.1 \mu \mathrm{M}$.

Liquid bactericidal assay

Bactericidal activity was quantitatively assessed in low protein binding polypropylene microtiter plates (Costar Corning). Bacteria from logarithmic phase cultures in trypticase soy broth (TSB; BD Difco) were washed twice with incubation buffer containing $10 \mathrm{mM}$ phosphate buffer $\mathrm{pH} 7.0$ supplemented with $1 \%(\mathrm{v} / \mathrm{v})$ TSB and were suspended at a concentration of $5 \times 10^{6} \mathrm{CFU} / \mathrm{ml}$, based on optical density. A $50 \%(\mathrm{v} / \mathrm{v})$ stock solution of honey was freshly prepared in incubation buffer. For enrichment with AMPs, an aliquot of $1.2 \mathrm{mM}$ LL-37 or BP2 stock solutions 
was added to $50 \%$ honey solutions to obtain $37.5 \mu \mathrm{M}$ of peptide, thus, corresponding to the enrichment of undiluted honey with $75 \mu \mathrm{M}$ of the respective peptides. Eighty microliters of diluted honey was mixed with $20 \mu \mathrm{l}$ of a bacterial inoculum containing $5 \times 10^{6} \mathrm{CFU} / \mathrm{ml}$, and the plates were incubated at $37^{\circ} \mathrm{C}$ on a rotary shaker at $150 \mathrm{rpm}$. At indicated time points, duplicate $10-\mu \mathrm{l}$ aliquots of undiluted and ten-fold serially diluted suspensions were plated on blood agar. The dilutions were prepared in incubation buffer containing $0.025 \%$ sodium polyanethol sulfonate (SPS; Sigma), which neutralizes cationic bactericidal components [25]. Bacterial survival was quantified after overnight growth at $37^{\circ} \mathrm{C}$. The detection level of this assay is $100 \mathrm{CFU} / \mathrm{ml}$.

To determine the LC99.9 values of LL-37 and BP2, 25- $\mu$ l aliquots of two-fold serially diluted peptide in incubation buffer were prepared in polypropylene microtiter plates (Costar Corning) and to each of the wells, $25 \mu$ of a bacterial suspension containing $2 \times 10^{6}$ $\mathrm{CFU} / \mathrm{ml}$ was added. After $2 \mathrm{~h}$ of incubation on a rotary shaker at $150 \mathrm{rpm}$ at $37^{\circ} \mathrm{C}$, triplicate $10-\mu \mathrm{l}$ aliquots were plated on blood agar plates. The plates were inspected for growth after $24 \mathrm{~h}$. LC99.9 was defined as the lowest concentration of peptide which killed $>99.9 \%$ of the inoculum of $10^{6} \mathrm{CFU} / \mathrm{ml}$ after $2 \mathrm{~h}$.

Partial purification of bee defensin-1

We previously demonstrated that bee defensin- 1 is the only bactericidal factor in the $>5-\mathrm{kDa}$ fraction of RS honey [16]. To prepare a $>5-\mathrm{kDa}$ fraction, $15 \mathrm{ml}$ of $20 \%(\mathrm{v} / \mathrm{v})$ honey was centrifuged in a $5-\mathrm{kDa}$ molecular weight cut-off Amicon Ultra-15 tube (Millipore) at 4,000g for $45 \mathrm{~min}$ at room temperature. The $>5-\mathrm{kDa}$ retentate was subsequently washed three times in the filter tube with $15 \mathrm{ml}$ of demineralized water and concentrated to $0.3 \mathrm{ml}$.

\section{Results}

Kinetics of the bactericidal activity of RS honey

We determined the kinetics of the bactericidal activity of different dilutions of RS honey against various antibioticresistant pathogens. RS honey at a concentration of $40 \%$ $(\mathrm{v} / \mathrm{v})$ reduced the survival of MRSE, VREF, ESBLproducing P. aeruginosa, and Burkholderia cepacia to undetectable levels within $2 \mathrm{~h}$, while similar activity against MRSA and ESBL E. coli required $6 \mathrm{~h}$ of incubation (Fig. 1). RS honey at a concentration of $20 \%$ killed B. cepacia within $4 \mathrm{~h}$ of incubation, while activity against all other bacteria required $24 \mathrm{~h}$ of incubation (Fig. 1). RS honey diluted to $10 \%$ killed MRSA and
MRSE after $24 \mathrm{~h}$, but lacked activity against all other bacteria tested (Fig. 1).

Even in undiluted RS honey, the survival of MRSA was not affected within $2 \mathrm{~h}$ (Fig. 2) of incubation and the numbers of CFU of $E$. coli $\mathrm{ESBL}$ were only reduced by $2.3-\log$. After $24 \mathrm{~h}$ incubation in undiluted honey, the survival of $E$. coli was reduced to undetectable levels, but the numbers of CFU of MRSA were only reduced by 1-log (Fig. 2). In summary, RS honey did not rapidly kill MRSA and E. coli ESBL, and rapid activity against all other species tested was abolished upon dilution of the honey to $\leq 20 \%$.

$\mathrm{H}_{2} \mathrm{O}_{2}$ concentration required for the rapid killing of MRSA

Since MRSA and E. coli ESBL were not rapidly killed by RS honey, we assessed whether the endogenous concentrations of bactericidal compounds in RS honey might be too low for rapid activity. The dilution of RS honey to $30 \%$ was optimal for $\mathrm{H}_{2} \mathrm{O}_{2}$ accumulation, resulting in maximal concentrations of $22.5 \pm 1.3 \mu \mathrm{g} / \mathrm{ml}$ and $148.4 \pm 27.8 \mu \mathrm{g} / \mathrm{ml}$ $\mathrm{H}_{2} \mathrm{O}_{2}$ after 2 and $24 \mathrm{~h}$, respectively (Fig. 3a). In incubations not containing honey but only $\mathrm{H}_{2} \mathrm{O}_{2}, 3,200 \mu \mathrm{g} / \mathrm{ml} \mathrm{H}_{2} \mathrm{O}_{2}$ was required to kill MRSA within $2 \mathrm{~h}$ (Fig. 3b). This is 142 times the concentration of $\mathrm{H}_{2} \mathrm{O}_{2}$ that maximally accumulated in RS honey after a similar 2-h incubation period, indicating that the $\mathrm{H}_{2} \mathrm{O}_{2}$ concentration in honey is far too low for rapid activity against MRSA. In view of possible toxicity (see the Discussion section), it is not feasible to increase the concentration of $\mathrm{H}_{2} \mathrm{O}_{2}$ in honey to the level required for rapid killing. For similar reasons, we did not assess the enrichment of RS honey with MGO.

Bee defensin-1 concentration required for the rapid killing of MRSA

Next, we assessed the contribution of bee defensin- 1 to the rapid bactericidal activity of RS honey. At the concentration present in undiluted RS honey, bee defensin-1 effectively killed Bacillus subtilis, a highly bee defensin-1-susceptible organism [16], within $2 \mathrm{~h}$ (Fig. 4a). However, this peptide had no substantial activity against MRSA, E. coli ESBL, or VREF (Fig. 4a). Even at an eight-fold higher concentration, bee defensin-1 reduced the numbers of CFU of MRSA after $2 \mathrm{~h}$ by only 1-log (Fig. 4b), indicating that it also was not feasible to enhance the rapid bactericidal activity of RS honey by increasing the concentration of bee defensin-1 .

Enhanced rapid bactericidal activity of LL-37-enriched honey

We subsequently assessed the potential of LL-37, a broadspectrum human AMP expressed in neutrophils and various 
Fig. 1 Kinetics of the killing of various antibiotic-resistant bacteria by RS honey. Bacteria were incubated in honey diluted to $40 \%$ (squares), $20 \%$ (triangles), and $10 \%$ (diamonds). At the indicated time points, survival was determined quantitatively

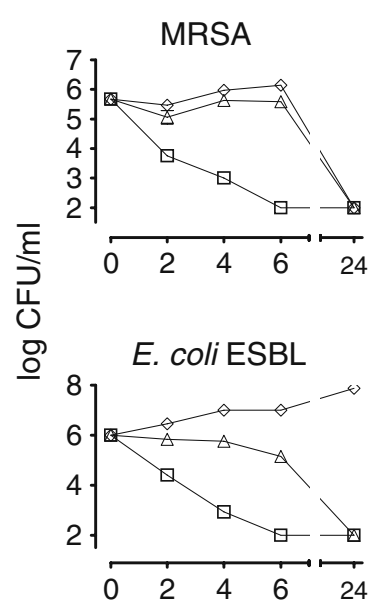

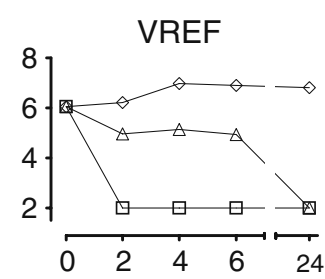

B. cepacia
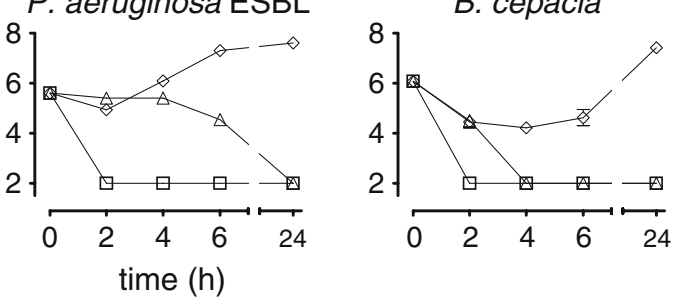

epithelial cells [26, 27], to enhance the rapid bactericidal activity of honey. RS honey was enriched with ten-fold excess $(75 \mu \mathrm{M})$ of the concentration of LL-37 required to reduce the survival of MRSA to undetectable levels (Fig. 5a). The lethal concentration of LL-37 for $99.9 \%$ of the inocula (LC99.9) of MRSA and E. coli in 2-h incubations were 7.5 and $1.9 \mu \mathrm{M}$, respectively (Fig. 5a). The enrichment of RS honey with LL-37 substantially improved the activity against E. coli ESBL and VREF, but not against other bacteria tested (Fig. 5b). LL-37-enriched honey retained bactericidal activity against $E$. coli ESBL and VREF up to 20 -fold dilution, which was a major improvement compared to non-enriched honey (Fig. 5b). The LC99.9 of LL-37 in honey, however, was four-fold higher than in incubation buffer (Fig. 5b), indicating that honey inhibited LL-37. Inhibition was even more clear from the tests with MRSA, MRSE, and P. aeruginosa. Enrichment with LL-37 did not substantially improve the activity of honey, while LL-37 alone effectively killed these bacteria (Fig. 5b).

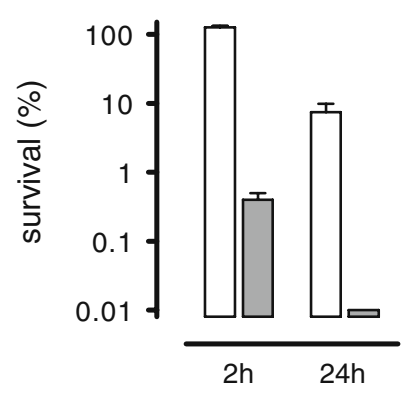

Fig. 2 Bactericidal activity of undiluted honey against methicillinresistant Staphylococcus aureus (MRSA) (white bars) and extendedspectrum beta-lactamase (ESBL)-producing Escherichia coli (gray bars). Inocula of approximately $10^{5} \mathrm{CFU}$ in $4 \mu 1$ were added to $0.5 \mathrm{ml}$ undiluted honey. At the indicated time points, samples were diluted with one volume of incubation buffer and, subsequently, survival was quantified as described for the liquid bactericidal assay

Enhanced bactericidal activity of BP2-enriched honey

The synthetic AMP BP2 has potent activity in physiological salt concentrations and in plasma, and is effective in vivo in a mouse model of biomaterial-associated infection [28]. The LC99.9 concentrations of BP2 for MRSA and E. coli in 2-h incubations were 1.9 and $3.8 \mu \mathrm{M}$, respectively (Fig. 6a). RS honey enriched with ten-fold excess $(75 \mu \mathrm{M})$ of the concentration of BP2 required to reduce the survival of MRSA to undetectable levels (Fig. 6a) retained bactericidal activity against all bacteria tested up to 20-fold dilution, except for P. aeruginosa (Fig. 6b), which was killed by up to a ten-fold dilution of this enriched RS honey (Fig. 6b). Non-enriched RS honey lacked rapid bactericidal activity for all bacteria tested when diluted more than 2.5 -fold.

The activity of BP2 against E. coli ESBL and VREF was not inhibited in honey (Fig. 6b). The killing of MRSA, MRSE, and P. aeruginosa ESBL required 2-4-fold higher

a

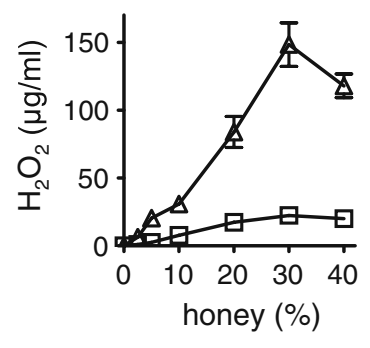

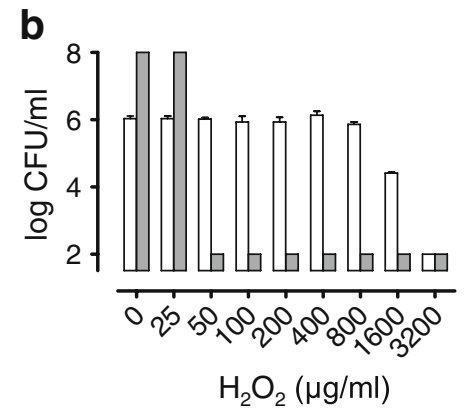

b

Fig. 3a, b Concentration of $\mathrm{H}_{2} \mathrm{O}_{2}$ required for activity against MRSA. a Production of $\mathrm{H}_{2} \mathrm{O}_{2}$ in diluted RS honey. The accumulation of $\mathrm{H}_{2} \mathrm{O}_{2}$ in indicated concentrations of RS honey was assessed at 2 $\mathrm{h}$ (squares) or $24 \mathrm{~h}$ (triangles) after dilution. b Bactericidal activity of solutions containing only $\mathrm{H}_{2} \mathrm{O}_{2}$. The survival of MRSA was assessed after $2 \mathrm{~h}$ (white bars) or $24 \mathrm{~h}$ (gray bars) of incubation with the indicated concentrations of $\mathrm{H}_{2} \mathrm{O}_{2}$ 
a

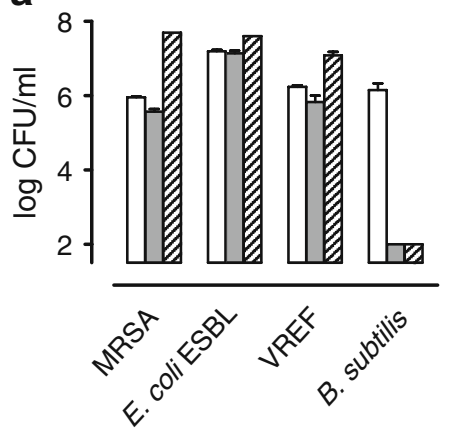

b

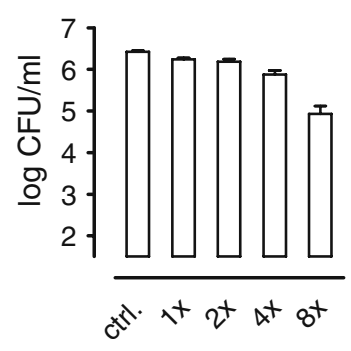

fold-concentation compared to RS honey

Fig. 4a, b The bactericidal activity of bee defensin-1 was assessed using the $>5-\mathrm{kDa}$ fraction of RS honey in which bee defensin- 1 is the only antibacterial factor present [16]. a Bactericidal activity of bee defensin-1 against various bacteria was assessed after $2 \mathrm{~h}$ (gray bars) or $24 \mathrm{~h}$ (hatched bars) of incubation at the concentration of this peptide as present in undiluted RS honey. As a control, bacteria were incubated for $2 \mathrm{~h}$ in incubation buffer (white bars). b Bactericidal activity of concentrated bee defensin-1 against MRSA after $2 \mathrm{~h}$ of incubation. Incubation in buffer was used as a control

concentrations of BP2 in honey than in buffer (Fig. 6b). This indicates a slight reduction of BP2 activity in honey, but markedly less than the observed inhibition of LL-37 in honey. We conclude that enrichment with $75 \mu \mathrm{M}$ BP2 markedly enhanced the rapid bactericidal activity of RS honey.

\section{Discussion}

The potent activity against antibiotic-resistant pathogenic bacteria makes honey an interesting agent to treat topical infections not responding to antibiotics. Ideally, honey used

a

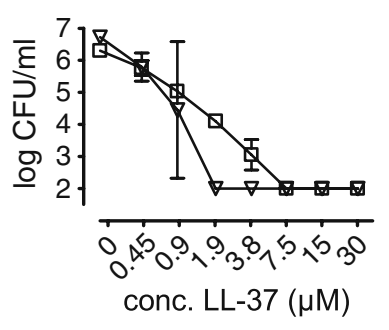

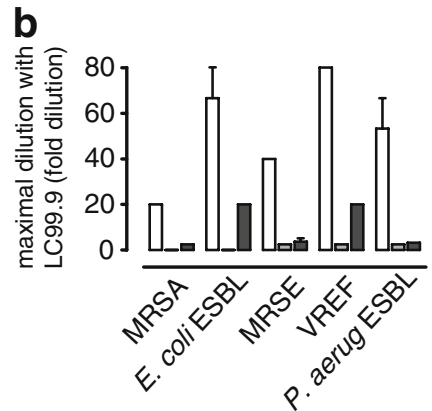

Fig. 5a, b Efficacy of LL-37 to enhance the rapid bactericidal activity of RS honey. a Survival of MRSA (squares) and E. coli ESBL (triangles) after $2 \mathrm{~h}$ of incubation in indicated concentrations of LL-37 in incubation buffer. b Bactericidal activity of LL-37-enriched RS honey. Indicated microorganisms were incubated for $2 \mathrm{~h}$ in two-fold serial dilutions of $75 \mu \mathrm{M}$ LL-37 (white bars), RS honey alone (gray bars), or RS honey enriched with $75 \mu \mathrm{M}$ LL-37 (black bars). The highest dilutions of these preparations killing at least $99.9 \%$ of the inocula are indicated. Mean \pm standard error of the mean (SEM) values of independent triplicate incubations are shown

for such applications should have rapid and broad-spectrum bactericidal activity. In addition, honey should remain active upon dilution, since honey will be rapidly diluted at the wound interface due to its hygroscopic characteristics and the presence of wound exudate.

RS honey has reproducible, broad-spectrum bactericidal activity in vitro and effectively reduces the microbial colonization of human skin [15]. Our present results, however, show that the activity of this honey against the major wound-infecting pathogens MRSA and E. coli ESBL is not rapid. Honey does have rapid activity against $P$. aeruginosa, E. faecium, and S. epidermidis, but this activity is lost when RS honey becomes diluted. Of note, $B$. cepacia, an otherwise notoriously antibiotic-resistant pathogen, proved to be the most honey-susceptible organism. Enhancement of the activity of RS honey with its endogenous microbicidal compounds appeared not to be feasible, but addition of the cationic AMP BP2 did increase the activity to the desired levels.

We recently identified all bactericidal factors in RS honey using an approach of successive neutralization of individual factors combined with activity-guided isolation of factors responsible for residual bactericidal activity [16]. Thus, we determined that the high sugar concentration, $\mathrm{H}_{2} \mathrm{O}_{2}$ production, $\mathrm{MGO}$, the low $\mathrm{pH}$, and bee defensin- 1 were responsible for the bactericidal activity of RS honey. In order to enhance the rapid bactericidal activity of RS honey, we first assessed the potential of $\mathrm{H}_{2} \mathrm{O}_{2}$ and of bee defensin-1. Upon the dilution of honey, $\mathrm{H}_{2} \mathrm{O}_{2}$ is produced by the glucose oxidase enzyme from the bees $[24,29]$. The production of $\mathrm{H}_{2} \mathrm{O}_{2}$ was highest in RS honey diluted to $30 \%$, in which 22.5 and $148 \mu \mathrm{g} / \mathrm{ml}$ accumulated after 2 and $24 \mathrm{~h}$, respectively. In a study with 90 different honeys, $12 \pm$

a
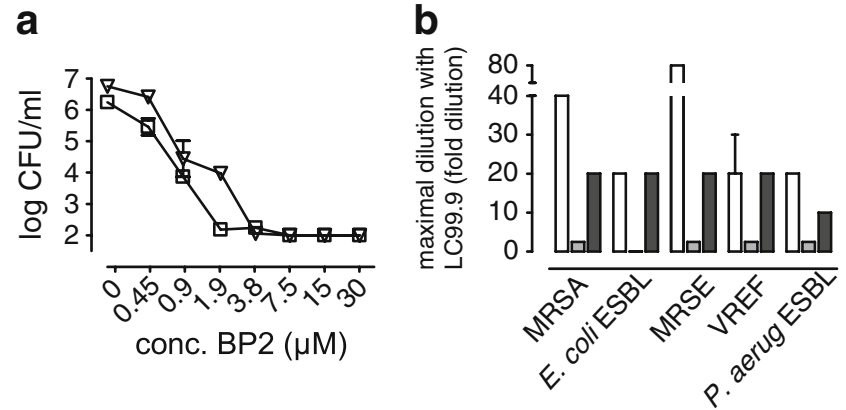

b

Fig. 6a, b Efficacy of bactericidal peptide 2 (BP2) to enhance the rapid bactericidal activity of RS honey. a Survival of MRSA (squares) and E. coli ESBL (triangles) after $2 \mathrm{~h}$ of incubation in indicated concentrations of BP2 in incubation buffer. b Bactericidal activity of $\mathrm{BP} 2$-enriched RS honey. Indicated microorganisms were incubated for $2 \mathrm{~h}$ in two-fold serial dilutions of $75 \mu \mathrm{M} \mathrm{BP} 2$ (white bars), RS honey alone (gray bars), or RS honey enriched with $75 \mu \mathrm{M}$ BP2 (black bars). The highest dilutions of these preparations killing at least $99.9 \%$ of the inocula are indicated. Mean \pm SEM values of independent triplicate incubations are shown 
$19 \mu \mathrm{g} / \mathrm{ml}$ hydrogen peroxide (range $0-72 \mu \mathrm{g} / \mathrm{ml}$ ) accumulated in honey diluted to $20 \%(\mathrm{w} / \mathrm{v})$ after $4 \mathrm{~h}$ [24], indicating that RS honey produces relatively high levels of $\mathrm{H}_{2} \mathrm{O}_{2}$.

MRSA is highly susceptible to $\mathrm{H}_{2} \mathrm{O}_{2}$-mediated killing by RS honey upon incubation for $24 \mathrm{~h}$ [16]. The killing of MRSA within $2 \mathrm{~h}$ by $\mathrm{H}_{2} \mathrm{O}_{2}$ in the absence of honey required a concentration as high as $3,200 \mu \mathrm{g} / \mathrm{ml} \mathrm{H}_{2} \mathrm{O}_{2}$ (corresponding to a $0.32 \%(\mathrm{w} / \mathrm{v})$ solution). Wound cleansing with a $3 \%(\mathrm{w} / \mathrm{v})$ solution of $\mathrm{H}_{2} \mathrm{O}_{2}$ has been a clinical practice, but at this concentration, $\mathrm{H}_{2} \mathrm{O}_{2}$ is toxic to human cells and skin tissue, and tissue exposure can result in delayed wound healing [30-32] . Although the concentration of $\mathrm{H}_{2} \mathrm{O}_{2}$ required to kill MRSA was about ten-fold lower than the concentration used for wound cleansing, we did not consider increasing the levels of $\mathrm{H}_{2} \mathrm{O}_{2}$ as a possibility to improve the rapid bactericidal activity of RS honey.

Bee defensin-1 (also referred to as royalisin [33]) is a 51residue AMP identified in honey bee hemolymph, royal jelly, and in honey $[16,33,34]$. Because of its complicated folding with three intramolecular cysteine bonds, the synthetic production of bee defensin-1 is not possible and recombinant production would be highly challenging. Bee defensin-1 effectively kills $B$. subtilis but lacks activity against all other bacteria tested at a concentration equivalent to that in undiluted honey. Even at an eight-fold higher concentration, bee defensin-1 only slightly reduced the survival of MRSA. The narrow spectrum of its bactericidal activity renders bee defensin- 1 unsuited for enhancement of the bactericidal activity of honey.

MGO is present in RS honey at a relatively low concentration $(0.25 \mathrm{mM})$ compared to the concentrations reported for Manuka honey (up to $16.1 \mathrm{mM}$ ) [12]. MGO is a reactive metabolite that can exert toxic effects by the direct inhibition of enzymes, by genomic modifications resulting in carcinogenesis, and by protein modifications resulting in the formation of advanced glycation end products [35]. The latter are believed to be the main determinants for pathological effects related to diabetes [36, 37]. Because of the concerns regarding the potential toxicity of MGO, we did not pursue to augment the activity of RS honey with this compound.

Other honey bactericidal factors are the high sugar concentration and low pH. Honey is a super-saturated sugar solution, so it is not possible to further increase its sugar concentration. RS honey has a $\mathrm{pH}$ of 3.2 , which is at the lower end of the $\mathrm{pH}$ range found for honeys (3.2-4.5) [16]. Even such a low $\mathrm{pH}$ only contributed to the activity against $B$. subtilis after $24 \mathrm{~h}$ of incubation, and not to the activity against other bacterial species [16]. Therefore, the sugar concentration and low $\mathrm{pH}$ were not suited as factors for the enhancement of the bactericidal activity of honey.

In contrast to bee defensin-1, most AMPs have broadspectrum bactericidal activity. The human $\alpha$-helical AMP
LL-37 is one of the best characterized AMPs [38-41]. Despite its potent activity in incubation buffer, LL-37 was strongly inhibited in the presence of honey. BP2 is a synthetic AMP with very rapid broad-spectrum microbicidal activity, which is retained in plasma and in physiological salt solution [28]. BP2 also effectively kills $S$. epidermidis in vivo, in a murine model of biomaterialassociated infection [28], indicating its potential for clinical application. The activity of BP2 against $E$. coli ESBL and VREF was not inhibited in honey, and activity against MRSA, MRSE, and P. aeruginosa ESBL required only slightly higher (2-4-fold) concentrations in honey than in buffer. Thus, BP2 was certainly suited for the enrichment of honey.

B. cepacia is notorious for its intrinsic resistance against antibiotics [42, 43] and AMPs [44], and is, indeed, not susceptible to LL-37 [44] or to BP2 [28]. Our results demonstrate, however, that $B$. cepacia is relatively susceptible to honey compared to other tested bacteria, which is in accordance with the findings of Cooper et al. [45]. Not surprisingly, the addition of BP2 to RS honey did not enhance the bactericidal activity against $B$. cepacia (not shown).

In summary, we were able to enhance the bactericidal activity of honey by enrichment with the AMP BP2. BP2enriched RS honey had rapid bactericidal activity up to a high dilution against all bacteria tested and had a broader spectrum of bactericidal activity than either agent alone. This offers prospects for the development of clinically applicable honey-based antimicrobials with rapid and broad-range microbicidal activity.

Funding This work was supported by a SENTER grant (TSGE2055) from the Dutch Ministry of Economic Affairs.

Conflict of interest None to declare.

Open Access This article is distributed under the terms of the Creative Commons Attribution Noncommercial License which permits any noncommercial use, distribution, and reproduction in any medium, provided the original author(s) and source are credited.

\section{References}

1. Walsh C (2003) Antibiotics: actions, origins, resistance. American Society for Microbiology (ASM) Press, Washington

2. Levy SB, Marshall B (2004) Antibacterial resistance worldwide: causes, challenges and responses. Nat Med 10:S122-S129

3. Fischbach MA, Walsh CT (2009) Antibiotics for emerging pathogens. Science 325:1089-1093

4. Cooper RA, Molan PC, Harding KG (2002) The sensitivity to honey of Gram-positive cocci of clinical significance isolated from wounds. J Appl Microbiol 93:857-863 
5. Efem SEE (1988) Clinical observations on the wound healing properties of honey. Br J Surg 75:679-681

6. Bonn D (2003) Sweet solution to superbug infections? Lancet Infect Dis 3:608

7. Dixon B (2003) Bacteria can't resist honey. Lancet Infect Dis 3:116

8. Lusby PE, Coombes A, Wilkinson JM (2002) Honey: a potent agent for wound healing? J Wound Ostomy Continence Nurs 29:295-300

9. Simon A, Traynor K, Santos K, Blaser G, Bode U, Molan P (2009) Medical honey for wound care - still the 'latest resort'? Evid Based Complement Alternat Med 6:165-173

10. Molan PC (1992) The antibacterial activity of honey. 2. Variation in the potency of the antibacterial activity. Bee World 73:59-76

11. Allen KL, Molan PC, Reid GM (1991) A survey of the antibacterial activity of some New Zealand honeys. J Pharm Pharmacol 43:817-822

12. Adams CJ, Boult CH, Deadman BJ, Farr JM, Grainger MN, Manley-Harris M, Snow MJ (2008) Isolation by HPLC and characterisation of the bioactive fraction of New Zealand manuka (Leptospermum scoparium) honey. Carbohydr Res 343:651-659

13. Mavric E, Wittmann S, Barth G, Henle T (2008) Identification and quantification of methylglyoxal as the dominant antibacterial constituent of Manuka (Leptospermum scoparium) honeys from New Zealand. Mol Nutr Food Res 52:483-489

14. Postmes T, van den Bogaard AE, Hazen M (1995) The sterilization of honey with cobalt 60 gamma radiation: a study of honey spiked with spores of Clostridium botulinum and Bacillus subtilis. Experientia 51:986-989

15. Kwakman PHS, Van den Akker JPC, Güçlü A, Aslami H, Binnekade JM, de Boer L, Boszhard L, Paulus F, Middelhoek P, te Velde AA, Vandenbroucke-Grauls CMJE, Schultz MJ, Zaat SAJ (2008) Medical-grade honey kills antibiotic-resistant bacteria in vitro and eradicates skin colonization. Clin Infect Dis 46:16771682

16. Kwakman PHS, te Velde AA, de Boer L, Speijer D, Vandenbroucke-Grauls CMJE, Zaat SAJ (2010) How honey kills bacteria. FASEB J 24:2576-2582

17. Huang HW (2000) Action of antimicrobial peptides: two-state model. Biochemistry 39:8347-8352

18. Shai Y (2002) Mode of action of membrane active antimicrobial peptides. Biopolymers 66:236-248

19. Kobayashi S, Takeshima K, Park CB, Kim SC, Matsuzaki K (2000) Interactions of the novel antimicrobial peptide buforin 2 with lipid bilayers: proline as a translocation promoting factor. Biochemistry 39:8648-8654

20. Epand RM, Vogel HJ (1999) Diversity of antimicrobial peptides and their mechanisms of action. Biochim Biophys Acta 1462:11-28

21. Matsuzaki K (1999) Why and how are peptide-lipid interactions utilized for self-defense? Magainins and tachyplesins as archetypes. Biochim Biophys Acta 1462:1-10

22. Devine DA, Hancock RE (2002) Cationic peptides: distribution and mechanisms of resistance. Curr Pharm Des 8:703-714

23. Al Naiemi N, Duim B, Savelkoul PH, Spanjaard L, de Jonge E, Bart A, Vandenbroucke-Grauls CM, de Jong MD (2005) Widespread transfer of resistance genes between bacterial species in an intensive care unit: implications for hospital epidemiology. J Clin Microbiol 43:4862-4864

24. White JW Jr, Subers MH (1963) Studies on honey inhibine. 2. A chemical assay. J Apic Res 2:93-100

25. Dankert J, van der Werff J, Zaat SAJ, Joldersma W, Klein D, Hess J (1995) Involvement of bactericidal factors from thrombinstimulated platelets in clearance of adherent viridans streptococci in experimental infective endocarditis. Infect Immun 63:663-671
26. Sørensen O, Arnljots K, Cowland JB, Bainton DF, Borregaard N (1997) The human antibacterial cathelicidin, hCAP-18, is synthesized in myelocytes and metamyelocytes and localized to specific granules in neutrophils. Blood 90:2796-2803

27. Frohm Nilsson M, Sandstedt B, Sørensen O, Weber G, Borregaard N, Ståhle-Bäckdahl M (1999) The human cationic antimicrobial protein (hCAP18), a peptide antibiotic, is widely expressed in human squamous epithelia and colocalizes with interleukin-6. Infect Immun 67:2561-2566

28. Kwakman PHS, te Velde AA, Vandenbroucke-Grauls CMJE, van Deventer SJH, Zaat SAJ (2006) Treatment and prevention of Staphylococcus epidermidis experimental biomaterial-associated infection by bactericidal peptide 2. Antimicrob Agents Chemother 50:3977-3983

29. Bang LM, Buntting C, Molan P (2003) The effect of dilution on the rate of hydrogen peroxide production in honey and its implications for wound healing. J Altern Complement Med 9:267-273

30. Lineaweaver W, Mcmorris S, Soucy D, Howard R (1985) Cellular and bacterial toxicities of topical antimicrobials. Plast Reconstr Surg 75:394-396

31. Wilson JR, Mills JG, Prather ID, Dimitrijevich SD (2005) A toxicity index of skin and wound cleansers used on in vitro fibroblasts and keratinocytes. Adv Skin Wound Care 18:373-378

32. Watt BE, Proudfoot AT, Vale JA (2004) Hydrogen peroxide poisoning. Toxicol Rev 23:51-57

33. Fujiwara S, Imai J, Fujiwara $M$, Yaeshima $T$, Kawashima $T$, Kobayashi K (1990) A potent antibacterial protein in royal jelly. Purification and determination of the primary structure of royalisin. J Biol Chem 265:11333-11337

34. Casteels-Josson K, Zhang W, Capaci T, Casteels P, Tempst P (1994) Acute transcriptional response of the honeybee peptideantibiotics gene repertoire and required post-translational conversion of the precursor structures. J Biol Chem 269:28569-28575

35. Kalapos MP (2008) The tandem of free radicals and methylglyoxal. Chem Biol Interact 171:251-271

36. Brownlee M (2001) Biochemistry and molecular cell biology of diabetic complications. Nature 414:813-820

37. Stitt AW (2003) The role of advanced glycation in the pathogenesis of diabetic retinopathy. Exp Mol Pathol 75:95-108

38. Zanetti M, Gennaro R, Romeo D (1995) Cathelicidins: a novel protein family with a common proregion and a variable Cterminal antimicrobial domain. FEBS Lett 374:1-5

39. Lehrer RI, Ganz T (2002) Cathelicidins: a family of endogenous antimicrobial peptides. Curr Opin Hematol 9:18-22

40. Niyonsaba F, Ogawa H (2005) Protective roles of the skin against infection: Implication of naturally occurring human antimicrobial agents beta-defensins, cathelicidin LL-37 and lysozyme. J Dermatol Sci 40:157-168

41. Pütsep K, Carlsson G, Boman HG, Andersson M (2002) Deficiency of antibacterial peptides in patients with morbus Kostmann: an observation study. Lancet 360:1144-1149

42. Govan JR, Deretic V (1996) Microbial pathogenesis in cystic fibrosis: mucoid Pseudomonas aeruginosa and Burkholderia cepacia. Microbiol Rev 60:539-574

43. Clore GM, Appella E, Yamada M, Matsushima K, Gronenborn AM (1990) Three-dimensional structure of interleukin 8 in solution. Biochemistry 29:1689-1696

44. Turner J, Cho Y, Dinh NN, Waring AJ, Lehrer RI (1998) Activities of LL-37, a cathelin-associated antimicrobial peptide of human neutrophils. Antimicrob Agents Chemother 42:2206-2214

45. Cooper RA, Wigley P, Burton NF (2000) Susceptibility of multiresistant strains of Burkholderia cepacia to honey. Lett Appl Microbiol 31:20-24 